
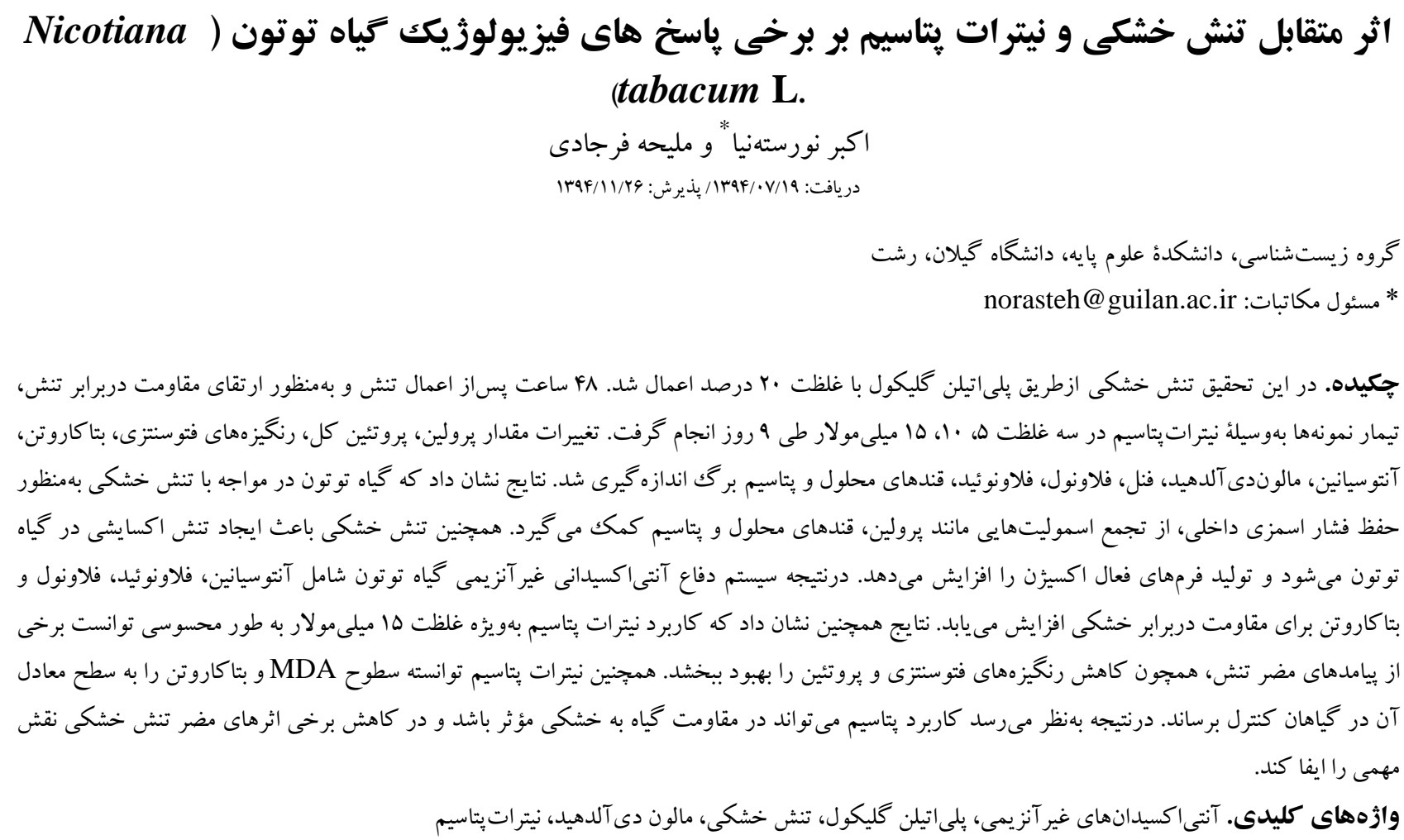

\title{
The effect of the interaction between water stress and potassium nitrate on some of the physiological responses of Nicotiana tabacum $\mathrm{L}$.
}

Akbar Norastehnia* and Maliheh Farjadi Received 11.10.2015/ Accepted 15.02.2016

Department of Biology, Faculty of Sciences, University of Guilan, Rasht, Iran

Correspondent author: norasteh@guilan.ac.ir

\begin{abstract}
In this study, water stress was applied by polyethylene glycol at a concentration of 20 perecentage. To improve the resistance of the plants, the samples were treated by potassium nitrate at concentrations 5,10 , and $15 \mathrm{mM}$ within 9 days. Changes in proline, total protein, photosynthetic pigments, carotene, anthocyanin, malondialdehyde, phenols, flavonols, flavonoids, soluble sugars and potassium ion were examined. The results showed that tobacco plants which had been exposed to drought used the accumulation of osmolytes such as proline, soluble sugars and potassium in order to balance their osmotic pressure. Drought stress also caused oxidative stress and increased the production of active forms of oxygen. As a result, non-enzymatic antioxidant defense system of tobacco plants including anthocyanins, flavonoids, flavonols and beta-carotene increased, which could be considered to be a major step for resistance to drought. The results also showed that the concentration of $15 \mathrm{mM}$ potassium nitrate in particular, could significantly improve some of the harmful effects of stress and reduced photosynthetic pigments and proteins. Potassium nitrate could also bring down the MDA and beta-carotene levels to equivalent levels in control plants. As a result, it seems that using potassium can affect plant resistance to drought and plays an important role to reduce some harmful effects of stress.
\end{abstract}

Keywords. nonenzymatic antioxidants, polyethylene glycol, drought stress, malondialdehyde, potassium nitrate 
Garg et al., ) سهبعدى بروتئين شود، جلو گيرى مى كنئ

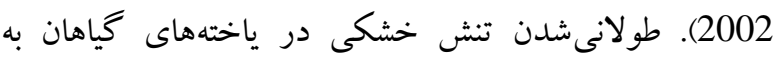

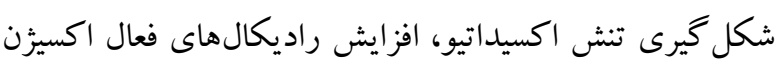

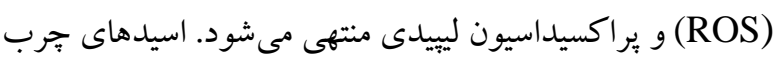
غيراشباع موجود در فسفولييدهاى غشا به حمله OH

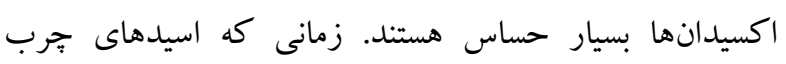

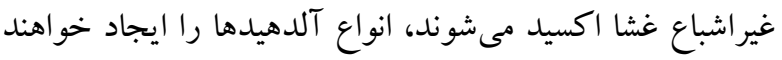

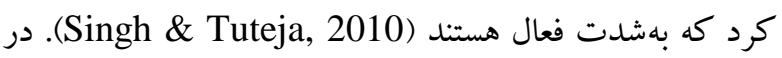
جنين وضعيتى، غالباً سنتز تركيبات فنلى شامل فلاند فلاونها، فلاونوئيدها، تاننها و ليخنينها و حتى حتى اسيدهاى آمينه حلقوى تئي مانند تريتوفان، تيروزين نيز افزايش مىيابد. اين تركيبها داراى نقشهاى متعدد اكولوزيكى و فيزيولوزيكى نظير نقشهاى دفاعى و آنتى اكسيدانى دارند (Andre et al., 2009). مقدار

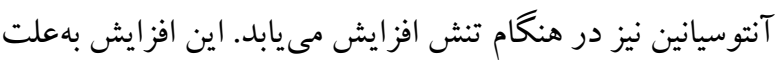

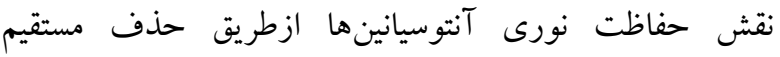

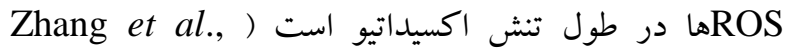

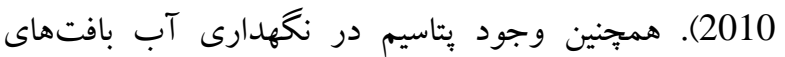

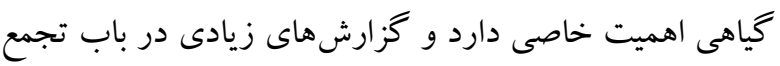
آن در هنگام تنش اسمزى وجود دارد (al., 2009. اين كاتيون در تنظيم فشار اسمزى و كنترل روزنه اى نقش ايفا مى كند (حميدى و صفرنزاد، الیبا). يتاسيم

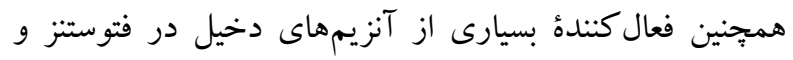

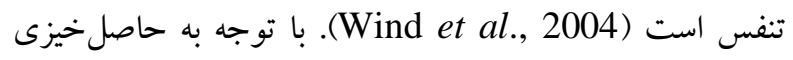

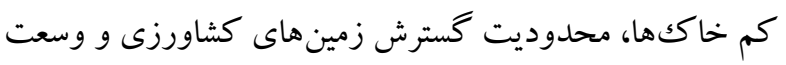
زياد مناطق خشك و نيمه خشك در بسيارى از مناطق دنيا و از -

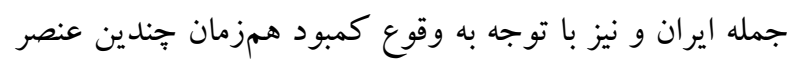

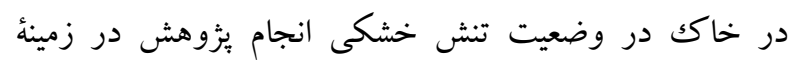

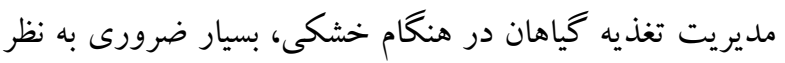

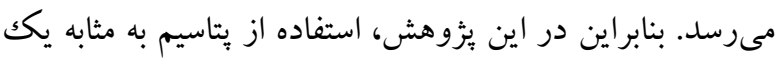

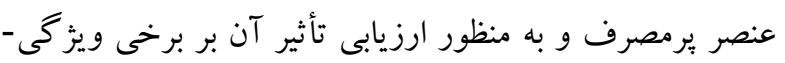

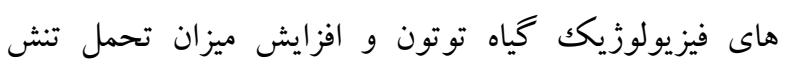
خشكى تحت بررسى قرار كرفت.
بخش عمدة كشت توتون در ايران به صورت ديم است

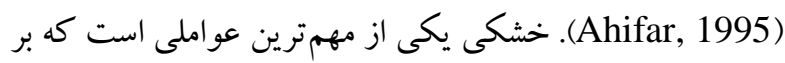

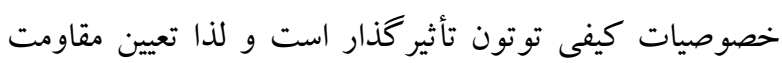

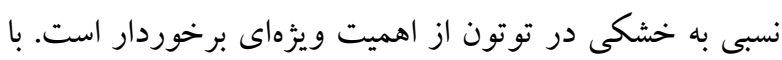

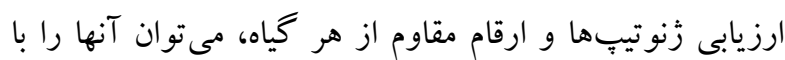
اطمينان بيشترى در مناطق خشك و نيمهخشك كاشت. تنش خشكى مى تواند باعث ايجاد تنش اكسيداتيو شود ( Chaves et (al., 2004 هاى كلروفيلى a و O Oliviera-Neto et al., 2009) b و Ort ) متعاقب آن كاهش توانايى فتوسنتز نقش ويزهاى ايفا كند et al., 2001

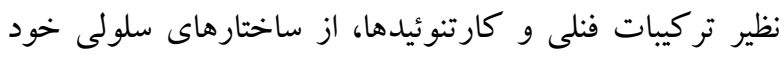

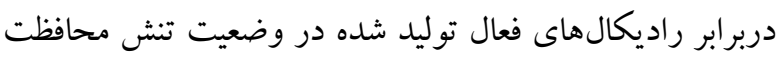

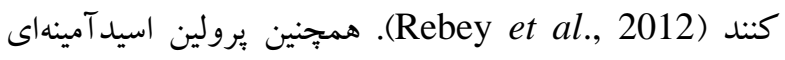

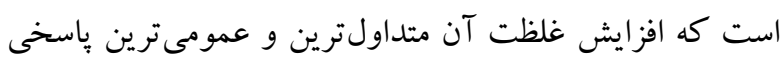

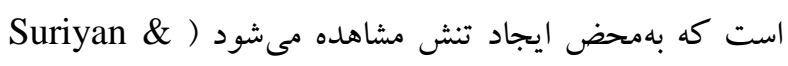

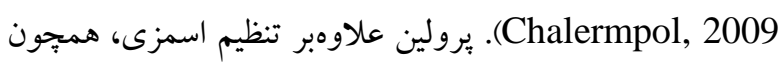

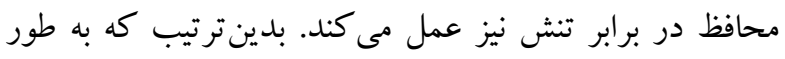

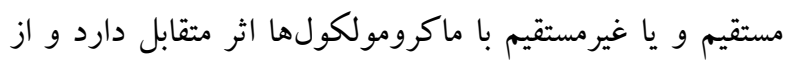

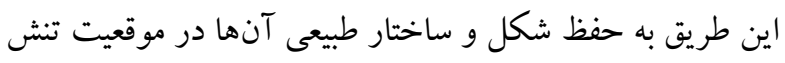

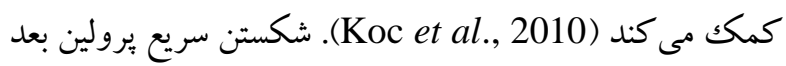

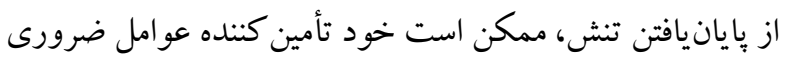

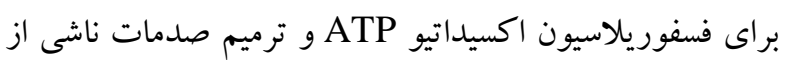

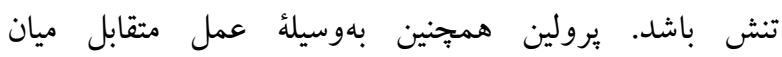

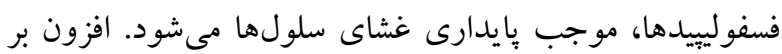

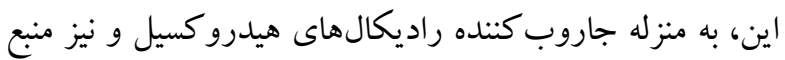
نيتروزن و ذخيره انرزى استفاده مىشود ( Vendruscolo et

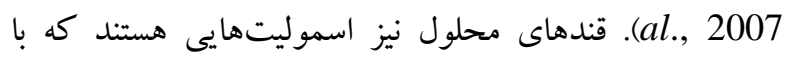

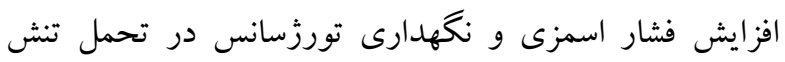
خشكى به گياه كمك مى كنند (Fayez \& Bazaid, 2014).

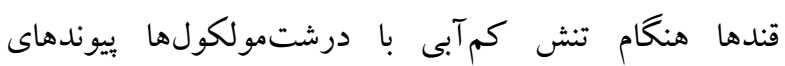

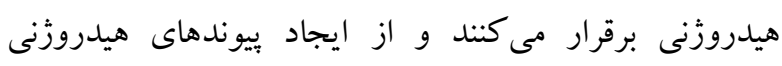

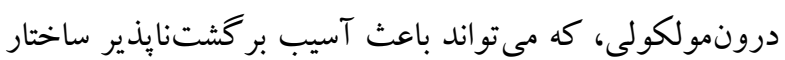


تيمارنشده با نيترات يتاسيم" (براى مقايسٔ باسخ طبيعى گياه با ناس

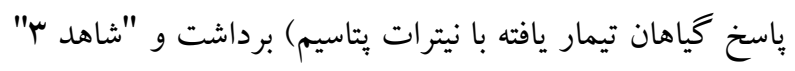

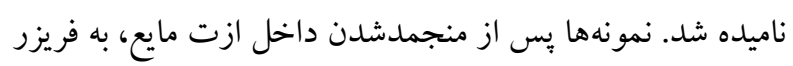

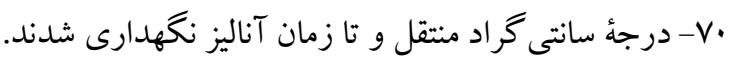

مقدار يرولين با استفاده از معرف نين هيدرين و براساس روش (1973) Bates Bradford منزلؤ منحنى استاندارد در طول موج

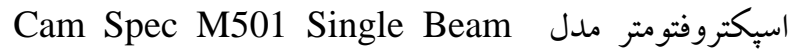
UV/Visible (1987) Lichtenthaler دآلدهيد با استفاده از روش Heath و Packer (1969) انجام شد. سنجش مقدار فنل كل با استفاده از روش Gao و همكاران Folin-Ciocalteu و و استاندارد كاليككاسيد انجام شد. به منظور استخراج عصاره جهت سنجش

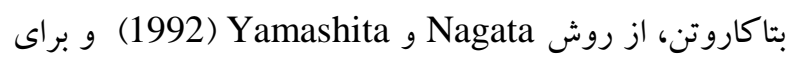
سنجش آنتوسيانين از روش Masukasu و همكاران (2003)

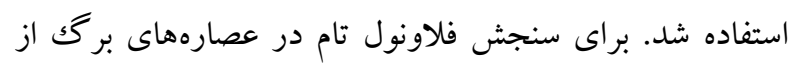
روش رنغك سنجى ( Venskutonis et al., 2010 and

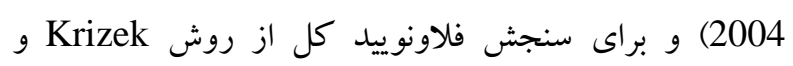

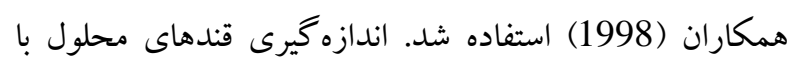
استفاده از روش Irigoyen و همكاران (1992) انجام شد. غلظت يون يتاسيم، بهوسيله دستگاه فليم اميشن اسبكترومتر و منحنى استاندارد بِتاسيم تعيين شد. (C M I Digital)

\section{تحليل آمارى}

براى بررسى آمارى دادهها از نرمافزار SPSS SPS و براى

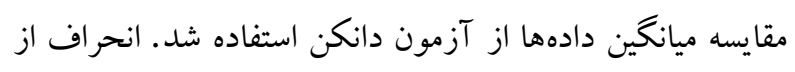

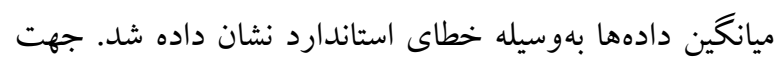
رسم نمودارها از نرمافزار 2007 Excel استفاده شد.

\section{مواد و روشها}

در اين تحقيق از بذرهاى توتون، رقم كوكر MFV استفاده شدكه

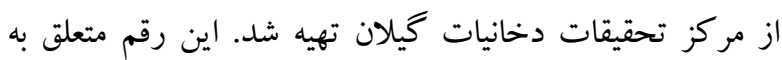

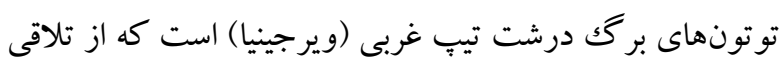

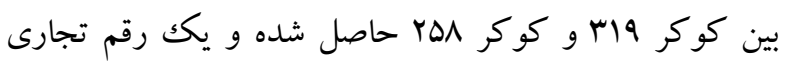
مناسب با وضعيت آب و هو ايى استانهاى شمال كشور است. دوهفته بِس از كاشت بذر توتون در يترىديش هاب، دانه رستهاى بهدست آمده به محيط كشت هيدرويونيك منتقل و با محلول

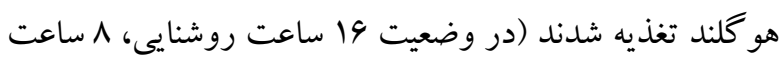

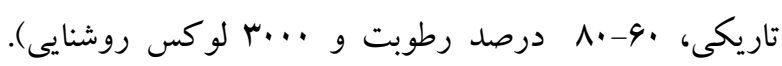

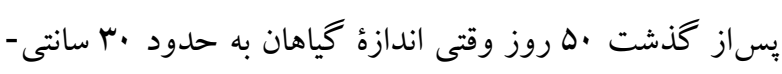

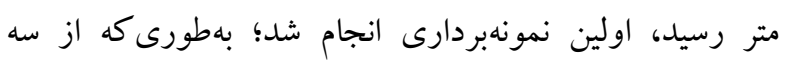

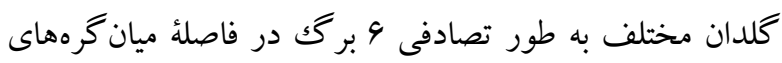

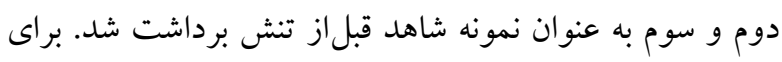

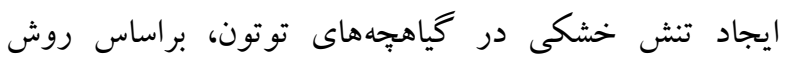

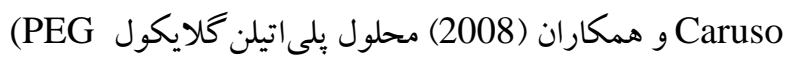

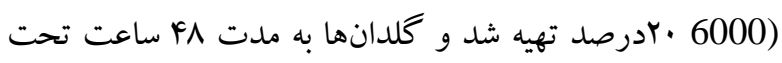

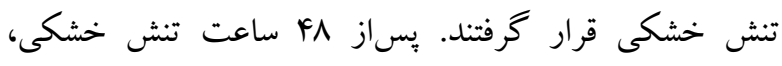

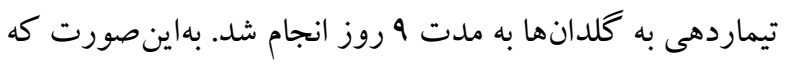

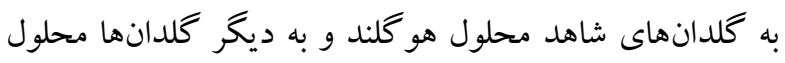

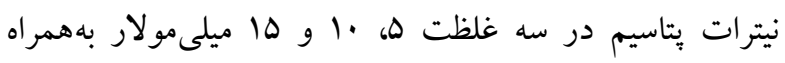
محلول هو كلند داده شد. پِ از اتمام دورهُ تنش دومين نمونه-

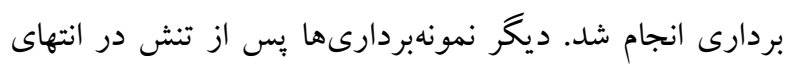

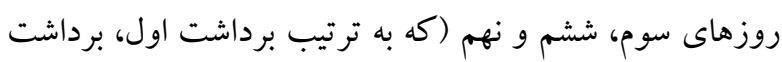

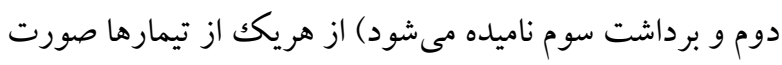

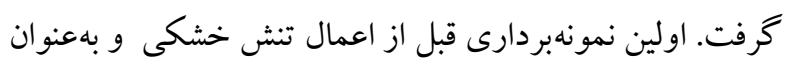

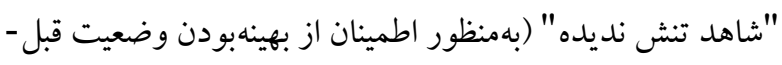
از اعمال تنش) صورت گرفت كه از اين بس "شاهد ا"ناميده

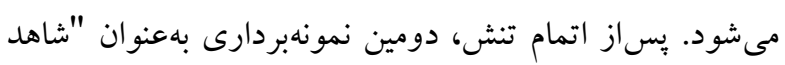

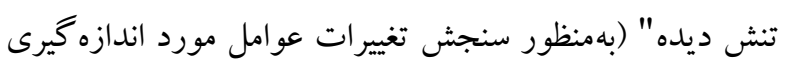

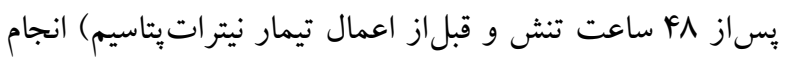
شد كه پِ از اين "شاهد ץ" ناميده مىشود. براى هريك از

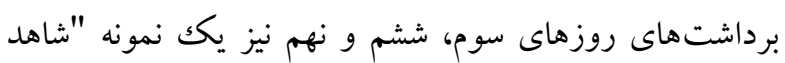


نشان داد و مقادير يرولين را حتى به بايينتر از نمونه شاهد r ra

رساند (شكل A (). مقادير بروتئين در نمونهاى تنشديده نسبت

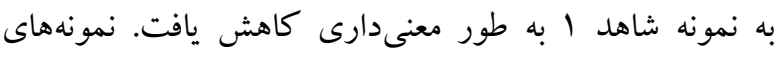

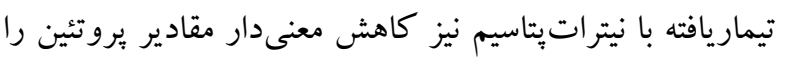
حتى نسبت به شاهد ب نشان دادند. در برداشت دوم، افت شديد

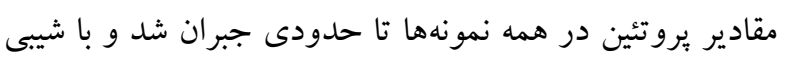
ملايم ارتقا يافت. شيب افزايش مقدار بروتئين در نمونههاى برداشت سوم نيز تداوم يافت و ارتقاى محسوس مقدار يروتئين

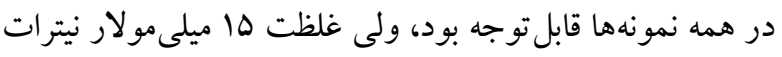

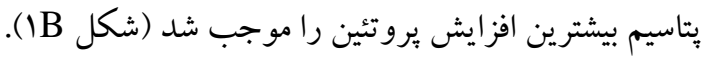

\section{نتايج سنجش محتواى يرولين و يروتئين كل}

مقادير برولين در نمونههاى شاهد Y تحت تأثير تنش خشكى

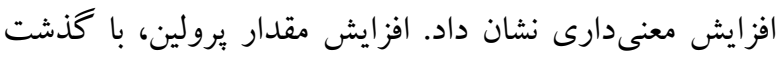

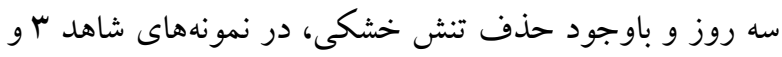
تمام نمونههاى تيماريافته پساز تنش نيز ادامه يافت. اما در برداشت سوم، روند افزايش برولين براى نمونههاى تيماريافته متوقف و براى نمونههاى شاهد ب معكوس شد. اما غلظت 10

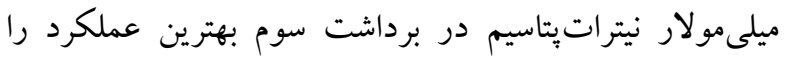
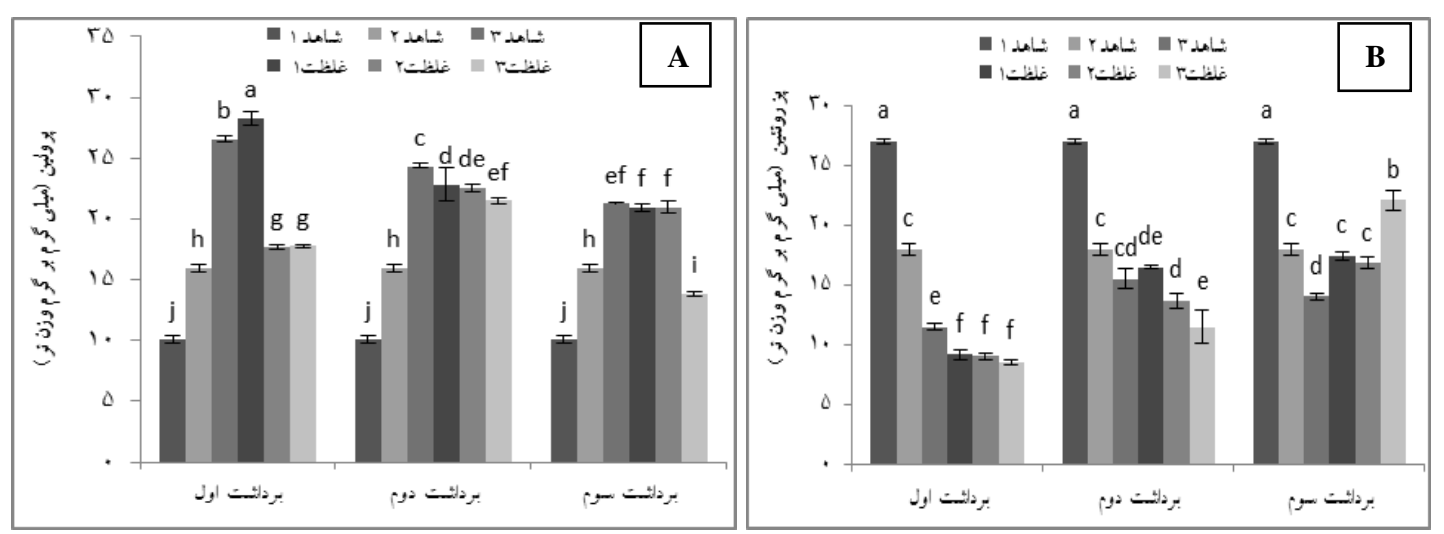

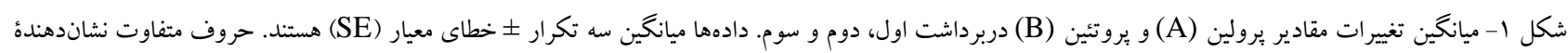

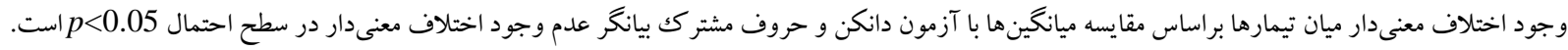

Fig. 1. Average changes in the quantities of proline (A) and protein (B) in the first, second and third harvests. The data represents the average of three replicates \pm standard error (SE), respectively. Different letters indicate significant differences among treatments according to Duncan's test with $p<0.05$.

ولى محتواى كلروفيلى را در هنگام تنش خشكى در سطوح

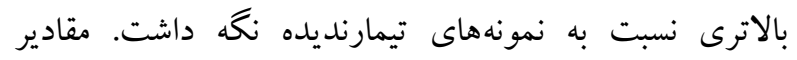

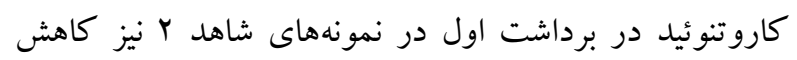

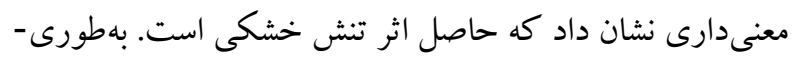

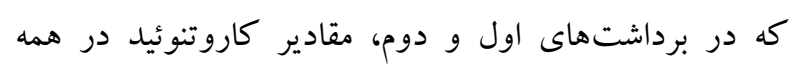

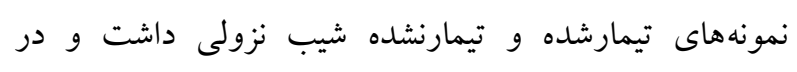

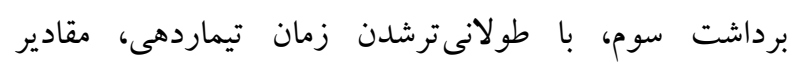

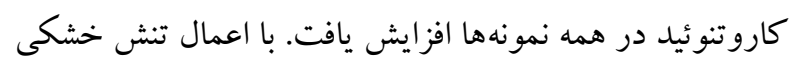

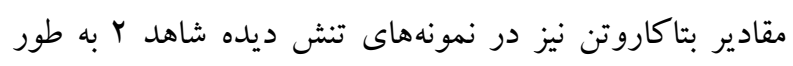

\section{نتايج اندازهيرى رنكيزههاى فتوسنتزى}

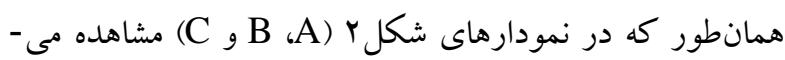

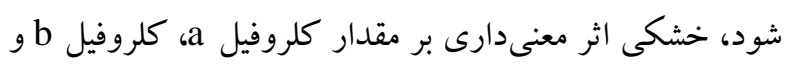

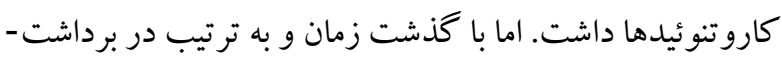

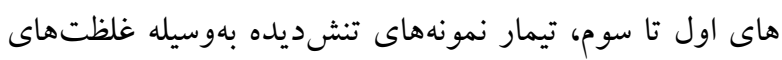

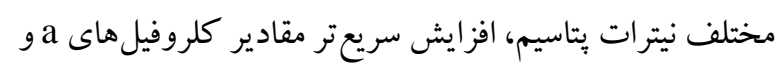

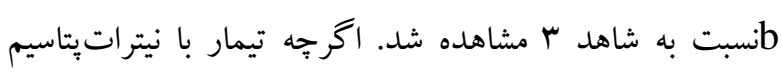

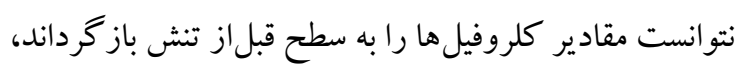




$$
\begin{aligned}
& \text { معنىدارى كاهش يافت. افزايش دوباره مقادير بتاكاروتن تحت بتاسيم در هيج يكك از نمونههاى آزمايشى معنىدار نبود (دادهها } \\
& \text { اثر تيمار نمونهاى تنشديده با غلظتهاى مختلف نيترات }
\end{aligned}
$$
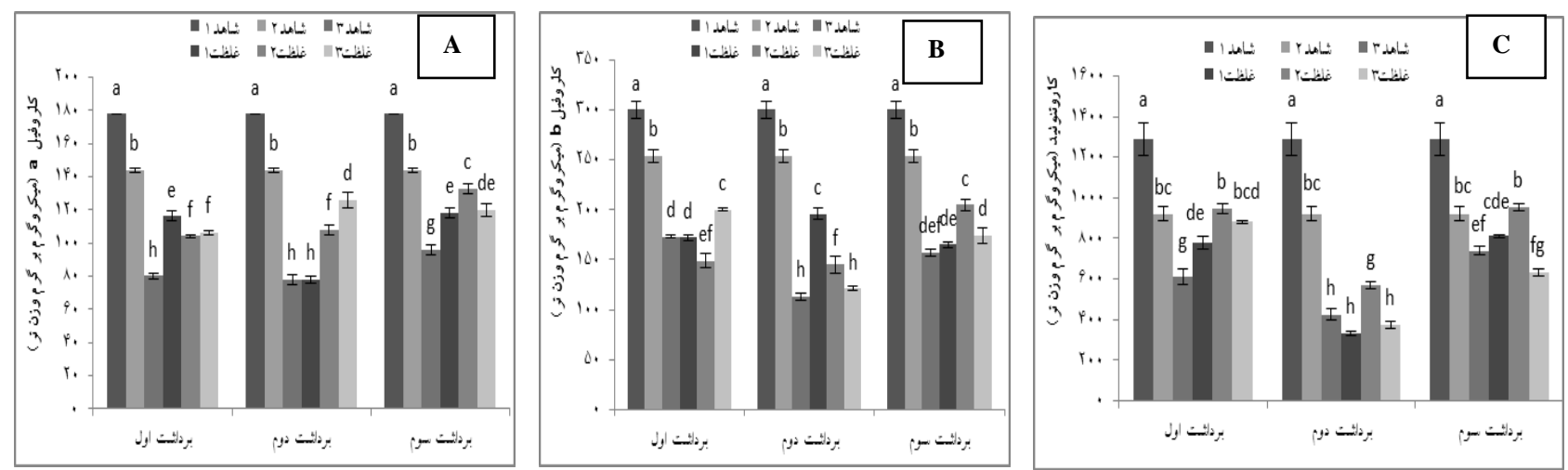

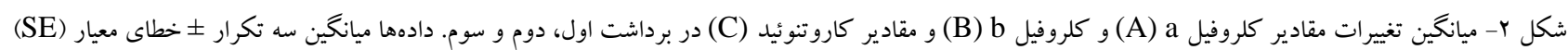

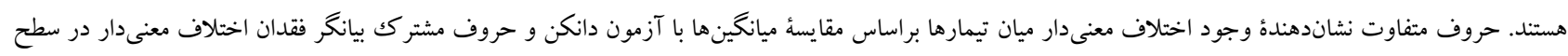
احتمال 0.05<p

Fig. 2. Average changes in the amount of Chlorophyll a (A), chlorophyll b (B) and carotenoid (C) in the first, second and third harvests. The data represents the average of three replicates \pm standard error (SE), respectively. Different letters indicate significant differences among treatments according to Duncan's test with $p<0.05$.

تحت تيمار با نيتراتيتاسيم، كاهش درخور توجه فنل نسبت به

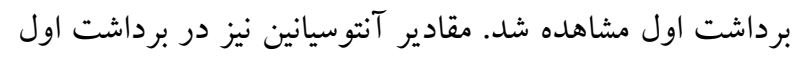

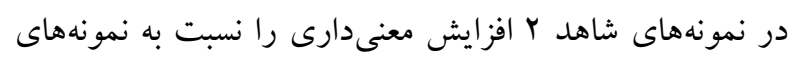

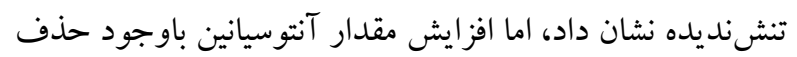

تنش خشكى در نمونههاى شاهد با و تمام نمونههاى تيماريافته

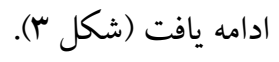

نتايج اندازهيرى تر كيبات فنلى

مقدار فنل تحت تأثير تنش خشكى و در برداشت اول در تمام

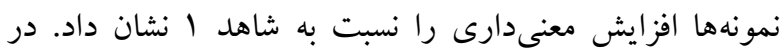
برداشت دوم و سوم، مقدار فنل براى نمونههاى فاقد تيمار نيترات

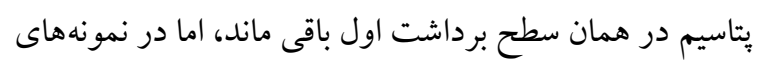
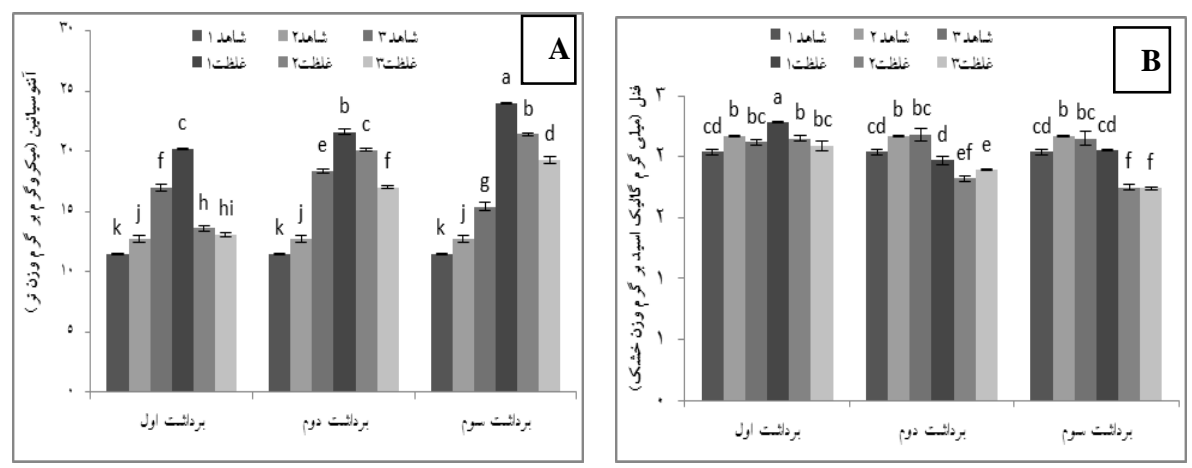

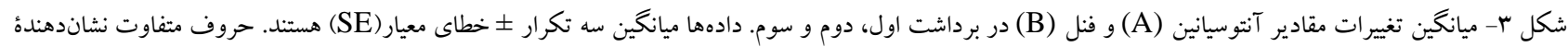

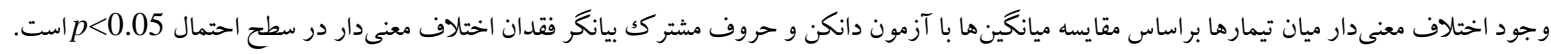
Fig. 3. Average changes in the amount of anthocyanin (A) and phenol (B) in the first, second and third harvests. The data represents the average of three replicates \pm standard error (SE), respectively. Different letters indicate significant differences among treatments according to Duncan's test with $p<0.05$. 
مقادير قندهاى محلول همجِنان بالا باقى ماند؛ درحالى كه با نتايج اندازه كيرى قندهاى محلول، وِتاسيم و مالون

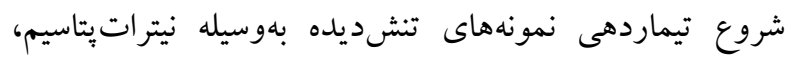
دآلدهيد در بركى

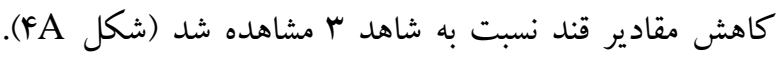

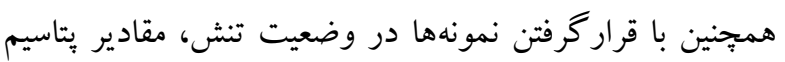
تنش خشكى مقادير قند را در نمونهاى شاهد Y به طور

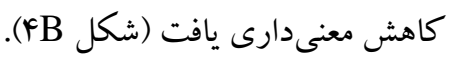

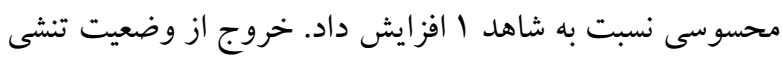

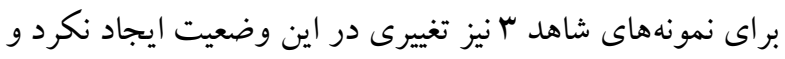

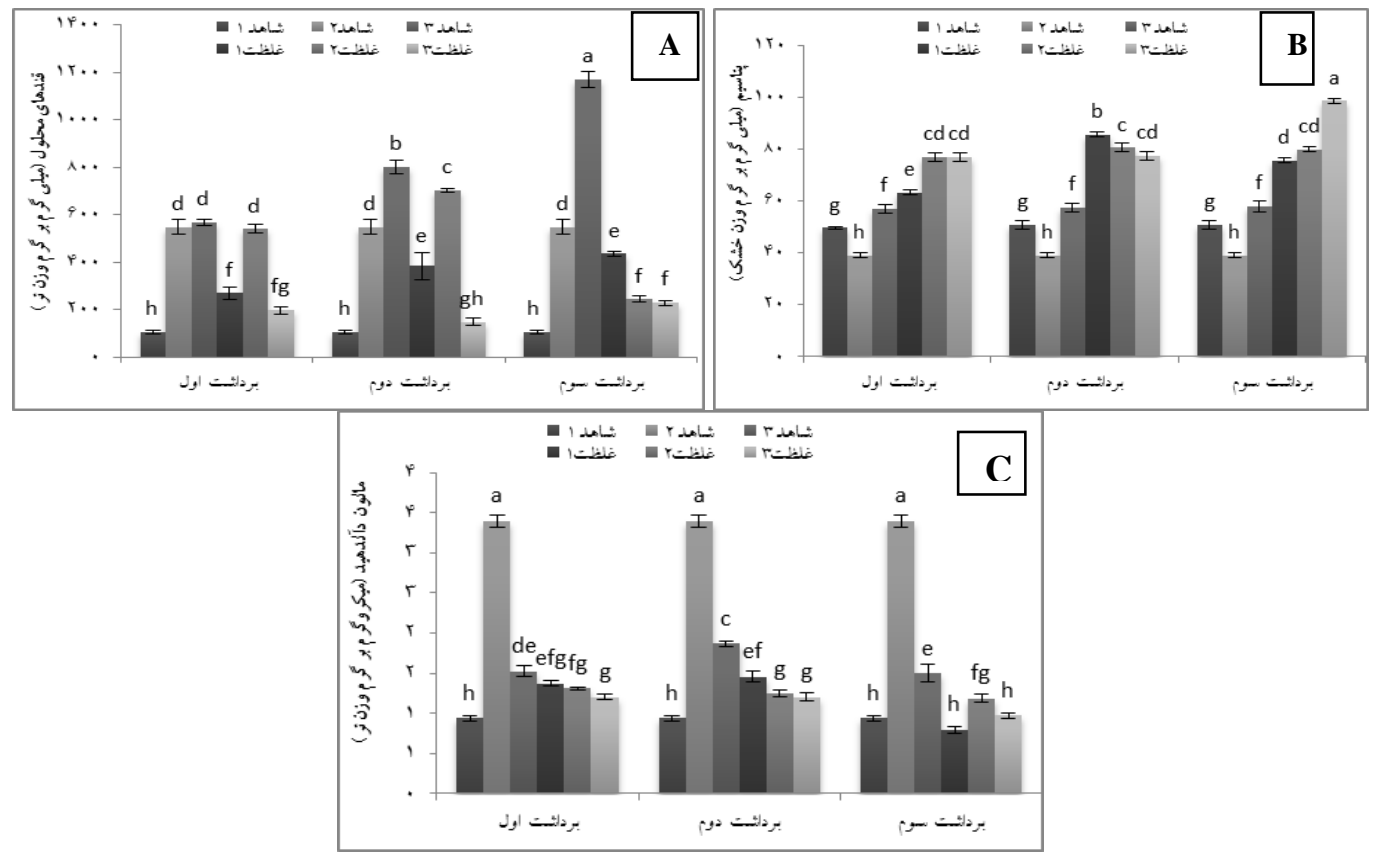

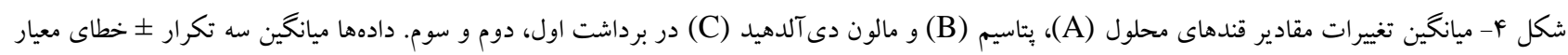

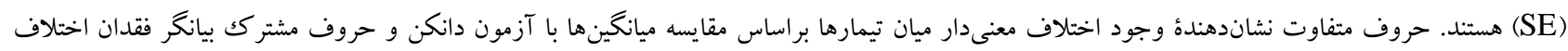
معنى دار در سطح احتمال 0.05>0 است.

Fig. 4. Average changes in the amounts of soluble sugars (A), potassium (B) and malondialdehyde (C) in the first, second and third harvests. The data represents the average of three replicates \pm standard error (SE), respectively. Different letters indicate significant differences among treatments according to Duncan's test with $p<0.05$.

براكسيداسيون لييدى را به اندازه نمونههاى تيماريافته با نيترات

$$
\text { يتاسيم كاهش دهند (شكل FC (F). }
$$

\section{بحث}

تنش خشكى ازطريق افزايش بيان آنزيمهاى بيوسنتز كنده

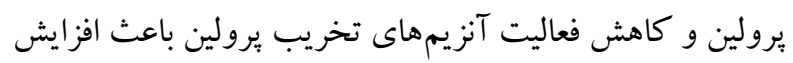
ميزان برولين در خياه مىشود (Serraj \& Sinclair 2002).

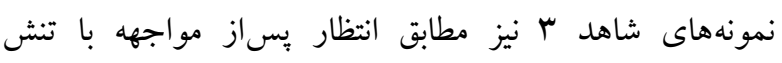

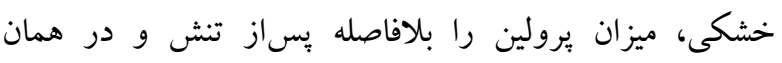

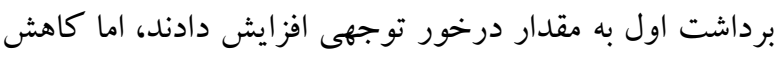

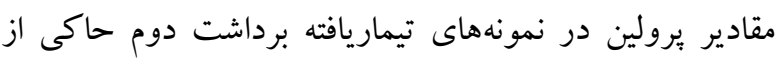

افزايش مقادير نيترات يتاسيم در محيط رشد گياهجهها، موجب

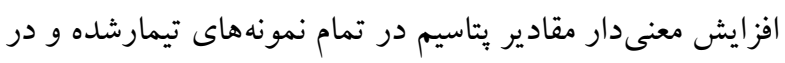
هر سه برداشت شد. تحت تنش خشكى، در مقدار مالوندى آلدئيد مربوط به نمونه-

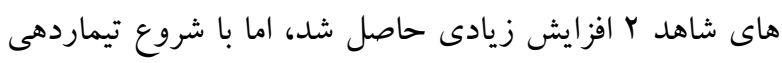

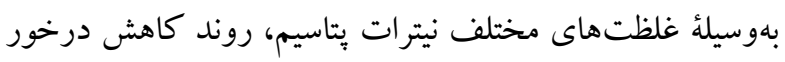

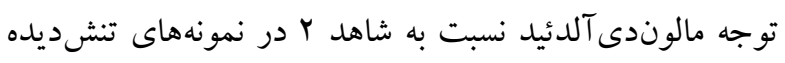
در هر سه برداشت اول، دوم و سوم مشاهده شد. نمونههاى شاهد r اما نتوانستند در وضعيت بهترى قرار بكيرند و ميزان 
سنتز يروتئين، تنظيم اسمزى، تعادل كاتيونى-آنيونى و تحمل

تنش دارد (Marschner, 2012).

كاهش مشاهدهشه در مقادير كلروفيل a و b در وضعيت تنش

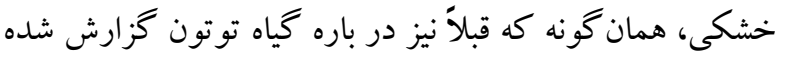
(Pastori \& Trippi, 1993)، بهعلت تخريب بيشتر كلروفيل نسبت به سنتز آن است (Thalooth et al., 2006). از دلايل ديخر كاهش مقدار رنخيزههاى فتوسنتى در وضعيت تنش، سنه مى توان عمدتاً به موارد تخريب ساختمان كلرويلاست و دستخاه فتوسنتزى، فتواكسيداسيون كلروفيلها، واكنش آنها با اكسيرن يكتايى، تخريب بيشمادهاى سنتز كننده كلروفيل و ممانعت از

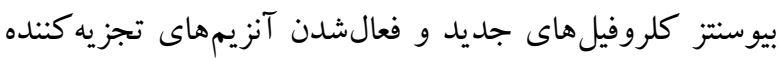
كلروفيل ازجمله كلروفيلاز و اختلالات هورمونى اشاره كرد (Neocleous et al., 2007) كياهان تحت تيمار و شاهد در برداشتهاى اول تا سوم نشان داد

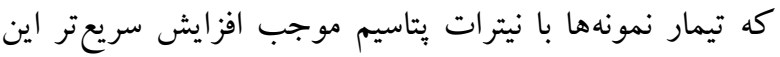

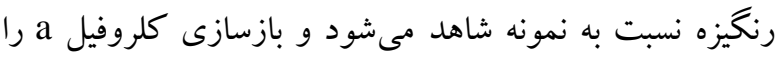

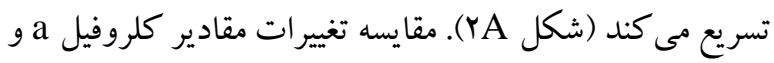
b نشان داد كه در اثر تنش خشكى، ميزان كاهش كلروفيل b

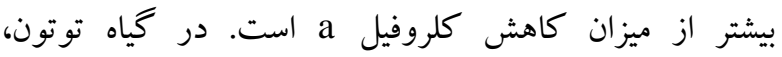

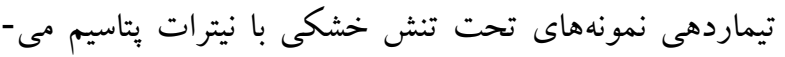

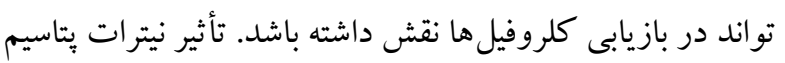

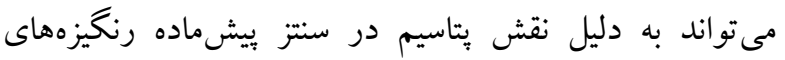

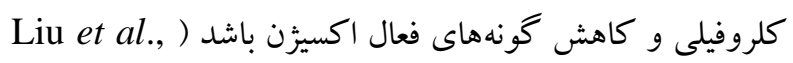

كمبود ملايم آب باعث افزايش كاروتنوئيدها مىشود (Jeyaramraja et al., 2005)؛ درحالى كه كمبود شديد آب

موجب كمشدن كاروتنوئيدها مىشود ( Munne-Bosch \&

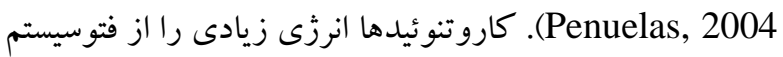

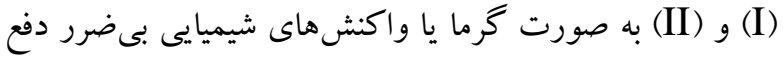
مى كنند و مىتواند غشاهاى كلرويلاستى را حفظ كنند (Koyro, 2006). با تيمار نمونههاى تنشديده بهوسيله نيترات

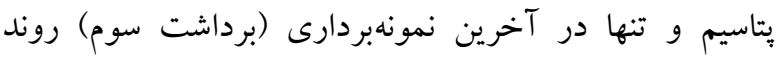
كاهشى كاروتنوئيدها متوقف مى شود و مقادير آنها نسبت به به بهرئ
تأثير مثبت نيتراتيتاسيم بر روند بهبودى و كاهش شدت تنش

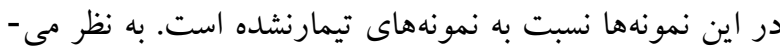
رسد كه در برداشت سوم زمان كافى براى كاستن از شدت تنش در اختيار گياهجهها بوده و سيستم دفاعى نمونههاى تنشديده توان كافى براى ساز گارى با اوضاع نامساعد محيطى را بيدا

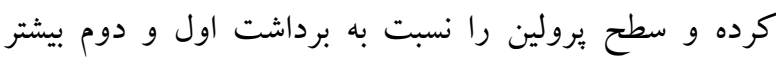

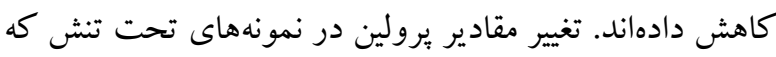
با نيتراتيتاسيم تيمار شدند به اين دليل است كه يتاسيم با فيا

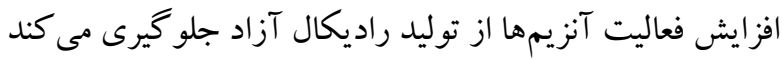
(Ma et al., 2004)

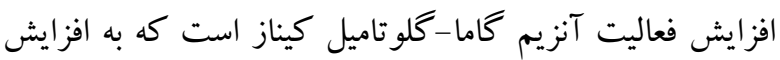
ميزان برولين منجر مىشود (Manivannan et al., 2007). ازطرف ديخر از طريق كمكك به جذب بيشتر آب در گياه منجر به تنظيم فشار اسمزى مىانجامد (Kanai et al., 2007). كزارشهاى زيادى وجود دارد كه كاهش مقدار بروتئين را Parry et al., 2002; Liu et al., ) نتيجه تنش در گياه توتون

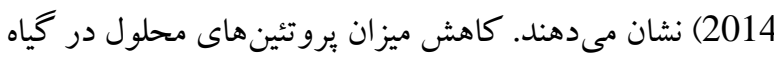
تحت تنش خشكى را مىتوان به افت شديد فر آيند فتوسنتز و متعاقب آن كاهش ييشمادههاى توليدكننده يروتئين نيز نسبت

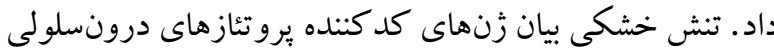
را القا مى كند و سبب تجزيه بروتئينها و تحر كك مجدد نيتروزن و متعاقب آن سنتز مواد محلول ساز گار مىشود. ازاينرو به نظر مىرسد كاهش محتواى يروتئين تحت تنش خشكى با كاهش سنتز بروتئين و افزايش فعاليت آنزيمهاى تجزيه كندهُ بروتئين

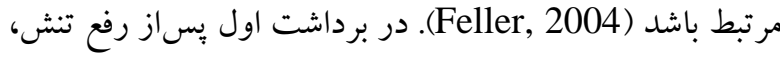
ازآنجاكه زمان كافى براى واكنش مناسب سيستم دفاعى كياهجِهاى توتون وجود نداشت، افزايش مقدار بِروتئين در

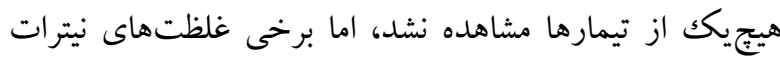
يتاسيم در برداشتهاى دوم و سوم موجب ارتقاى بهتر مقادير

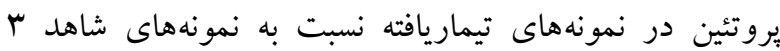

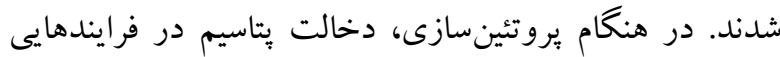

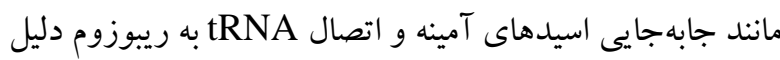
افزايش إبروتئين تحت تنش بيان شده است ( Ruiz \&

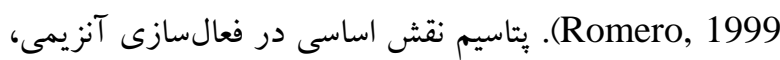


كونهاى واكنشخر اكسيزن عمل مى كنند و درنتيجه سبب ثبات

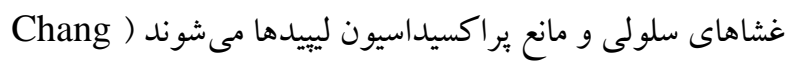

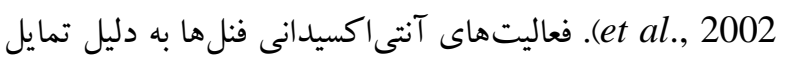

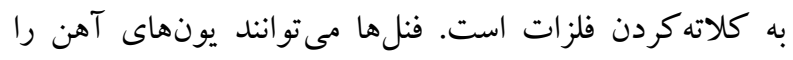

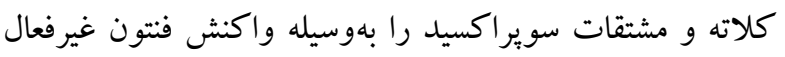

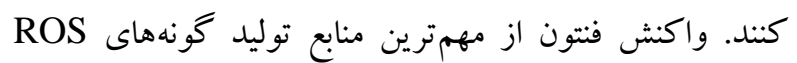

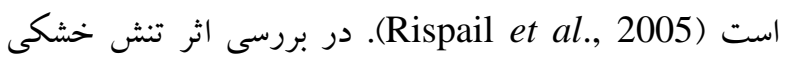

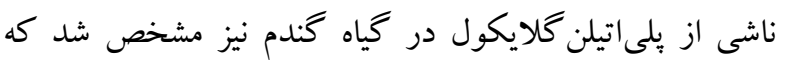

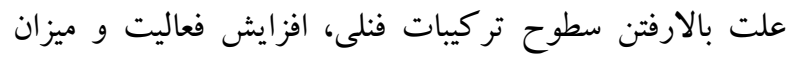

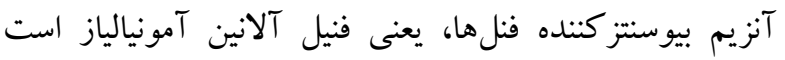

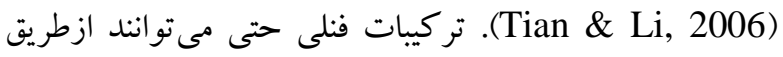
تأثير بر برخى ويزگى هاى مورفولوزيكى برگك (تعداد روزنه،

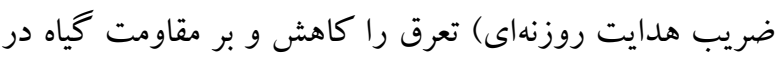

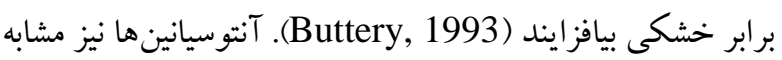

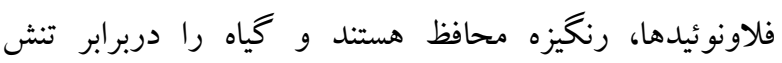

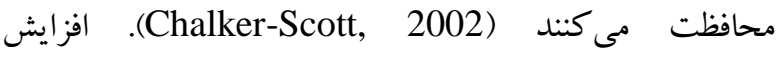
آنتوسيانين بهعلت نقش حفاظت نورى آنتوسيانين ازطريق حذف رهف

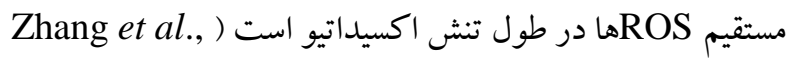

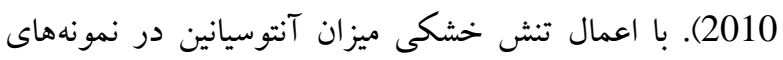
تنشديده نسبت به نمونه شاهد ا به طور معنىدارى افزايش نشان داد. حذف تنش و برداشت نمونهها پِساز سهروز (برداشت اول) نشان داد كه افزايش مقدار آنتوسيانين در همه نمونههاى تيمارشده و تيمارنشده با نيترات يتاسيم نسبت به شاهد r همجيجنان

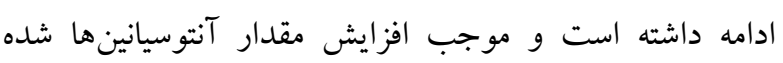
است. اين روند به طور مشابه در برداشتهاى دوم و سوم نيز

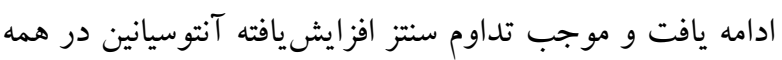

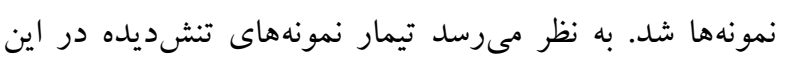

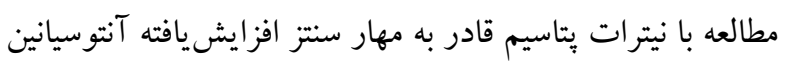

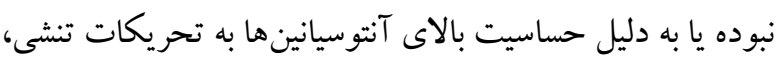
كاهش آنتوسيانين صورت نكرفته است. اين نتايج با مشاهدات Zhang و همكاران در باره بكونيا (2010) مطابقت دارد. نتايج تحقيق حاضر نيز نشان داد كه مقدار قندهاى محلول تحت

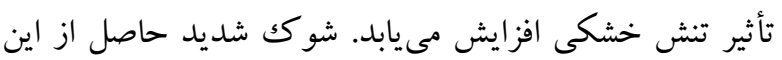

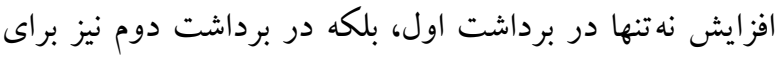

نمونه شاهد r به طور معنى دارى افزايش مىيابد. به نظر مىرسد

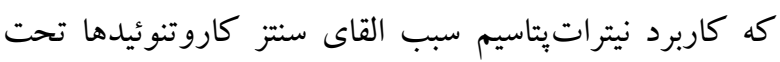
تنش مىشود. افزايش كاروتنوئيدها علاوهبر بهبود كيفيت فتوسنتز، به ارتقاى توان مقاومت آنتى اكسيدانى سلول كمكك مى كند و موجب كاهش صدمههاى ناشى از تنش اكسيداتيو مىشود؛ زيرا به دليل نقش حفاظتى كاروتنوئيدها در تشكيلات

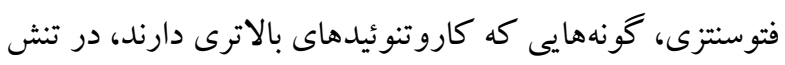

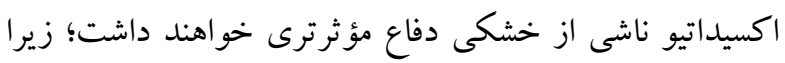
اين رنكيزهها مسئول خاموش كردن اكسيزن يكتايى و جلو كيرى دئن

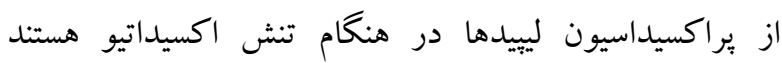
.(Koyro, 2006)

در طى تيمار نمونههاى تنشديده با نيترات يتاسيم در برداشت

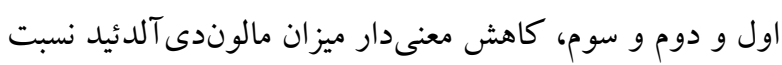
به شاهد Y مشاهده شد كه حاكى از مؤثربودن تهون تيمار نيترات يتاسيم بر كاهش تنش است. به نظر مىرسد كه تيماردهى نمونه -

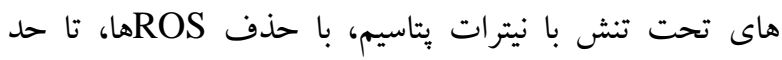

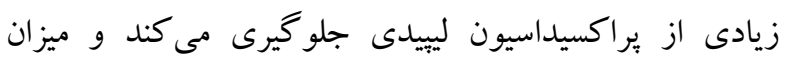
را كاهش مىدهد. درنتيجه كنترل تنش اكسيداتيو در

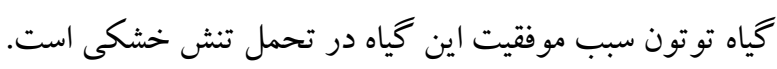
نتايج برداشت اول نشان مىدهد كه خشكى ميزان تركيبات فنلى

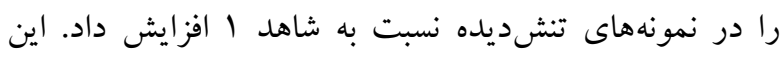

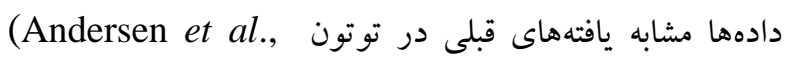

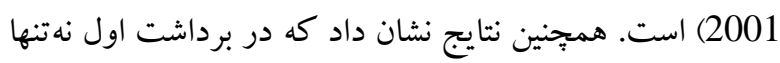

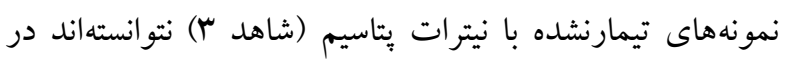

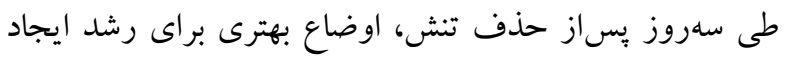

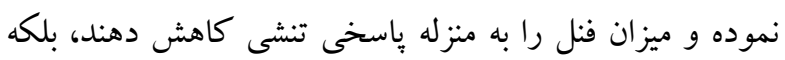

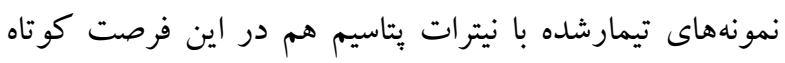

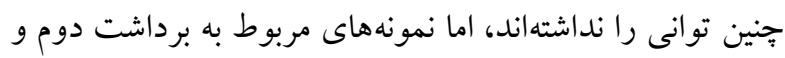

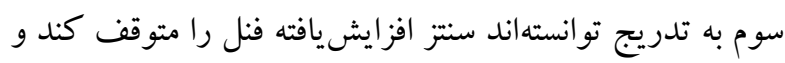
حتى به طور درخور توجهى كاهش دهند. ازجمله سازو كارهاى

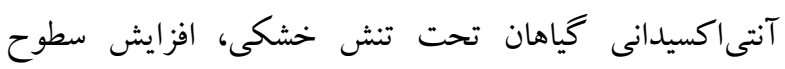
Rebey et al., 2011; Bettaieb et (تركيبات فنلى است استى

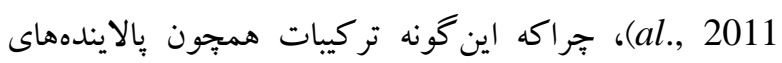


در اين بررسى گزارش شده است، تحت تأثير افزايش درون-

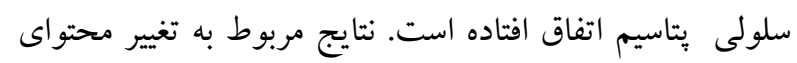

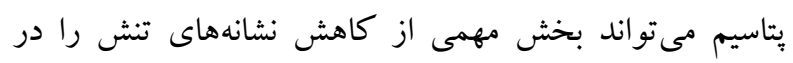

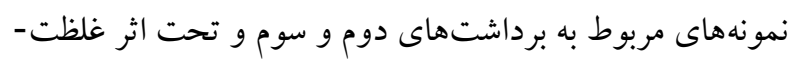

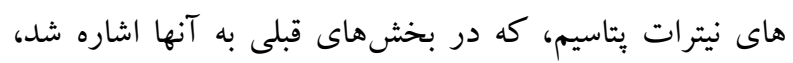

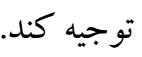

\section{نتيجه كيرى}

باتوجه به نتايج در اين بررسى، مىتوان اظهار كرد كه گياه

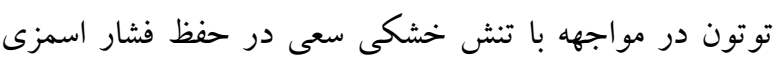

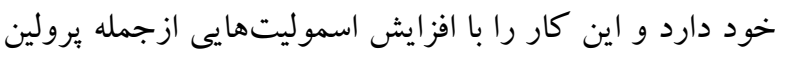

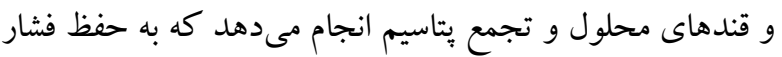

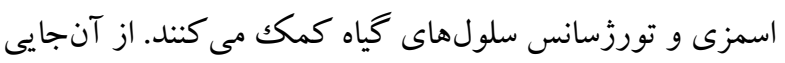
كه تنش خشكى باعث ايجاد تنش اكسايشى شده است و توليد

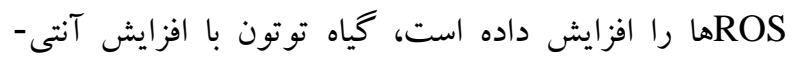

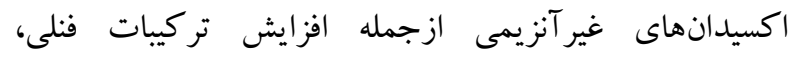

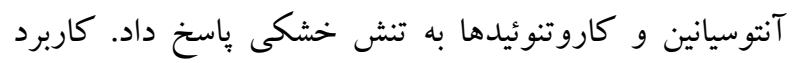
نيترات يتاسيم بهخصوص غلظت ها ميلىمولار نسبت به غلظتهاى ·لا و هميلى مولار به طور محسوسترى توانسته است برخى ليهى

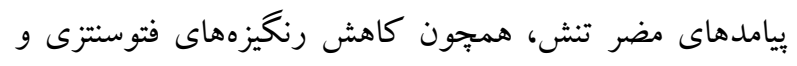

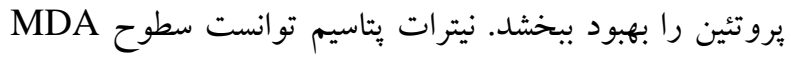

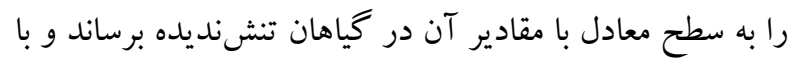
افزايش بروتئين تا حدودى بيامدهاى مخرب ناشى از تنش خشكى را بكاهد كه نشانه آن كاهش مقادير تركيبات فنلى و مقدار يرولين دربرابر غلظتهاى مختلف نيتراتيتاسيم است.

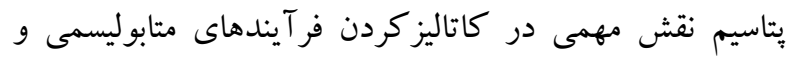
حفظ آماس سلولى در گياه برعهده دارد و موجب مىشود تا گياه عناصر ضرورى خود براى افزايش اسموليتها را بهتر و راحتتر بهدست آورد. بدين ترتيب سلول بهتر مىتواند در وضعيت تنش به فعاليتهاى حياتى خود ادامه دهد و درنهايت عملكرد بذيرفنتى ترى در هنگام تنش خواهد داشت. بـ براى جبران حداقل برخى اثرهاى مضر تنش خشكى و كمكك به گياه

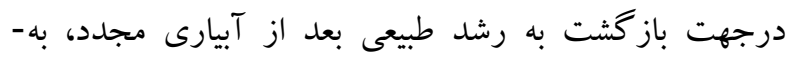

تمام نمونهها موجب افزايش قندهاى محلول شد. براى افزايش

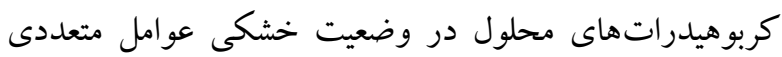

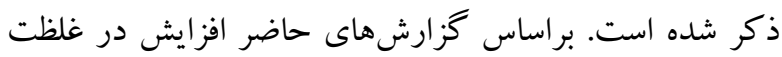

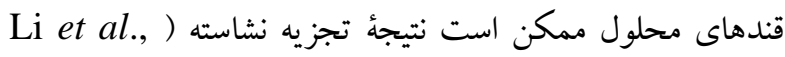

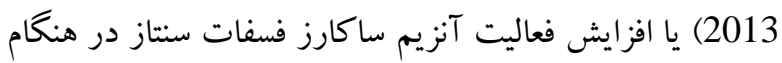
تنش (Plaue et al., 2004) باشد. همجِنين كاهش انتقال

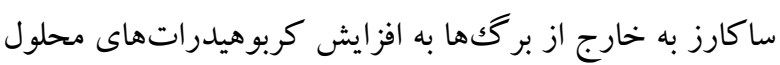

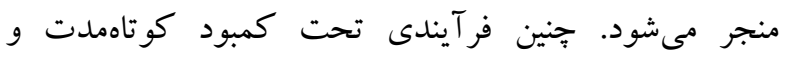
بلندمدت آب مشاهده شده است (Pereira et al., 1993).

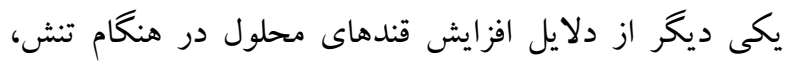

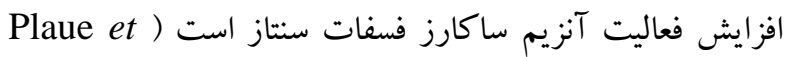

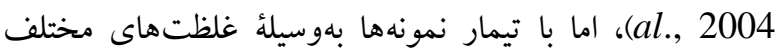
نيترات يتاسيم، اين سير صعودى متوقف مىشود و حتى موجب

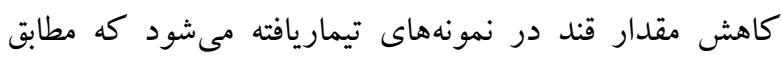
يافتهاى Fayez و Baid (2014) است. همجنين بيشنهاد شده است كه يتاسيم داراى نقش مهمى در انتقال قندها به منطقه انتهايى ريشه است (Saftner \& Wyse, 1980)، بنابراين افزايش بِتاسيم مىتواند با تسهيل نقل و انتقال قندهاى محلول، نقش مهمى در تنظيم اسمزى سلولهاى منطقه ريشه و درجهت

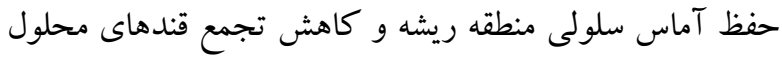
در بر كى برعهده داشته باشد.

بررسى محتواى يتاسيم نشان داد كه نمونهاى شاهد ب نسبت به

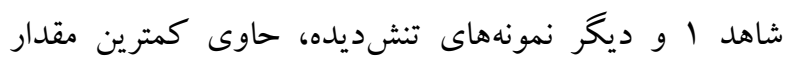
يتاسيم هستند. Cakmak (2005) و همجِين

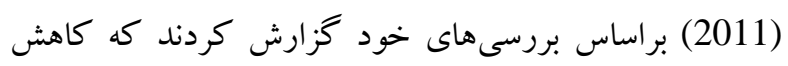
يتاسيم يكى از علائم تنش خشكى است. احتمالاً علت كاهش بـ برد بتاسيم در تنش خشكى، كاهش ميزان حلال گرى بـ بتاسيم و

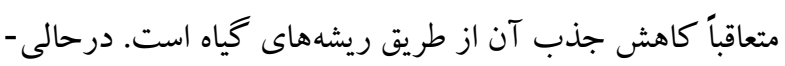
كه تيماردهى نمونههاى تنشديده با نيترات يتاسيم در برداشت اول و دوم و سوم باعث افزايش معنىدار مقادير بتاسيم نسبت به نمونه شاهد ا و شاهد r و شاهد r شد. بهنظر مىرسد كه افزايش دوره تيماردهى موجب افزايش محتواى داخلى نيترات بِتاسيم

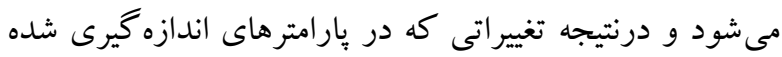




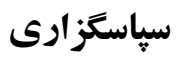

نكارند كان اين مقاله ضمن سياس فراوان از مر كز دخانيات استان

گيلان بابت تأمين بذرهاى توتون و از دانشگاه گيلان به خاطر

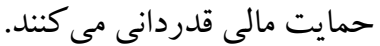

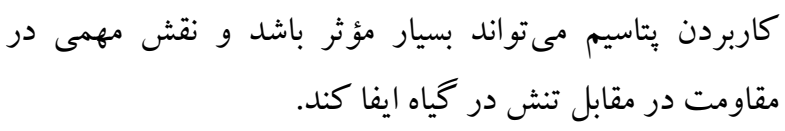

منابع/References

حميدى، ح. و صفرنزاد، ا. ای1ץا. بررسى خصوصيات مورفولوزيك و

بيوشيميايى كالوس يونجه و بازسازى در برابر تنش اسمزى. - يثوهش و و ورسي

سازندگ

Ahifar, H. 1995. Comparison of morphological, physiological and quantitative and qualitative performance of Tiklak and Trabzon varieties. Tirtash tobacco Research Institute, Research Workbook. Iranian Tobacco Company. pp: 26-16.

Andersen, R.A., Lowe, R. and Vaughn, T.A. 2001. Plant phenols and polyphenol oxidase in Nicotiana tabacum during greenhouse growth, field growth and air-curing. - Phytochemistry 8: 2139-2147.

Andre, C.M., Schafleitner, R., Legay, S., Lefèvre, I, Hausman, J.F., Larondelle, Y and Evers, D. 2009. Gene expression changes related to the production of phenolic compounds in potato tubers grown under drought stress. - Phytochemistry 70: 1107-1116.

Bates, L.S. 1973. Rapid determination of free proline for water stress studies. - Plant Soil 39: 205-207.

Bettaieb, I., Hamrouni-Sellami, I., Bourgou, S., Limam F. and Marzouk, B. 2011. Drought effects on polyphenol composition and antioxidant activities in aerial parts of Salvia officinalis L. - Acta Physiologiae Plantarum 33:1103-1111.

Bradford, M.M. 1976. A rapid and sensitive method for the quantification of microgram quantities of prot utilizing the principle of protein dye-binding. - Annal Biochemistry 38: 248-252.

Buttery，R.B.T., Buzzel， C.S., Gayron, J.D. and Matarish, D.C. 1993. Stomatal number of soybean and response to water stress. - Plant Soil 149: 283-288.

Cakmak, I. 2005. The role of potassium in alleviating detrimental effects of abiotic stresses in plants. - The Journal of Plant Nutrition and Soil Science 168: 521530.
Caruso, A., Chefdor, F., Carpin, S., Depierreux, C., Delmotte, F.M., Kahlem, G. and Morabito, D. 2008. Physiological characterization and identification of genes differentially expressed in response to drought induced by PEG 6000 in Populus canadensis leaves. Plant Physiology 165: 932-941.

Chalker-Scott, L. 2002. Do anthocyanins function as osmoregulators in leaf tissues? - Advances in Botanical Research 37: 103-106.

Chang, W.C., Kim, S.C., Hwang, S.S., Choi, B.K. and Kim, S.K. 2002. Antioxidant activity and free radical scavenging capacity between Korean medicinal plants and flavonoids by assay-guided comparison. - Plant Science 163: 1161-1168.

Chaves, M.M. and M.M. Oliveira. 2004. Mechanisms underlying plant resilience to water deficits: prospects for water-saving agriculture. - Journal of Expermental Botany 55: 2365-2384.

Fayez, K.A. and Bazaid, S.A. 2014. Improving drought and salinity tolerance in barley by application of salicylic acid and potassium nitrate. - Journal of the Saudi Society of Agricultural Sciences 13: 45-55.

Feller, U. 2004. Proteolysis. In: Plant Cell Death Processes. - Elsevier. pp. 107-123.

Gao, T., Jelle, B.P., Sandborg, L.I.C. and Gustavsen, A. 2013. Monodisperse hollow silica nanospheres for nano insulation materials: synthesis, characterization and life cycle assessment. - ACS Applied Materials \& Interfaces 5: 761-767.

Garg, A.K., Kim, J.K., Owens, T.G., Ranwala, A.P., Choi, Y.D., Kochian, L.V., and Wu, R.J. 2002. Trehalose accumulation in rice plants confers high tolerance levels to different abiotic stresses. 
Proceeding of the National Academy of Sciences USA 99: 15898-15903.

Heath, R.L. and Packer, L. 1969. Photoperoxidation in isolated chloroplast kinetics and stoichiometry of fatty acid peroxidation. - Archives of Biochemistry and Biophysics 125: 189-198.

Irigoyen, J.J., Emerich, D.W. and Sanchez-Diaz, M., 1992. Water stress induced changes in concentrations of proline and total soluble sugars in nodulated alfalfa (Medicago sativa) plants. - Plant Physiology 84: 55-60.

Jeyaramraja, P.R., Meenakshi, S.N., Kumar, R.S., Joshi, S.D. and Ramasubramanian, B. 2005. Water deficit induced oxidative damage in tea (Camellia sinensis) plants. - Plant Physiology 162: 413-419.

Kanai, S., Ohkura K., Adu-Gyamfi, J. Mohapatra, P. Saneoka, H. and Fujita, K. 2007. Depression of sink activity precedes the inhibition of biomass production in tomato plants subjected to potassium deficiency stress. - Journal of Experimental Botany 58: 29172928.

Koc, E., İslek, C. and Üstun, A.S. 2010. Effect of cold on protein, proline, phenolic compounds and chlorophyll content of two pepper (Capsicum anпиит L.) varieties. - Gazi University Journal of Science 23: $1-6$.

Koyro, H.W. 2006. Effect of salinity on growth, photosynthesis, water relations and solute composition of potential cash crop halophyte Plantago coronopus (L.). - Environmental and Experimental Botany 56: 136-149.

Krizek, D.T., Britz, S.J. and Mirecki, R.M. 1998. Inhibitory effects of ambient levels of solar UV-A and UV-B radiation on growth of $\mathrm{cv}$. new red fire lettuce. - Physiologia Plantarum 103: 1-7.

Li, M.H., Cherubini, P., Dobbertin, M., Arend, M., Xiao, W.F. and Rigling, A. 2013. Responses of leaf nitrogen and mobile carbohydrates in different Quercus species/provenances to moderate climate changes. Plant Biology 15: 177-184.

Lichtenthaler, H.K. 1987. Chlorophylls and carotenoids: pigments of photosynthetic biomembranes. - Methods in Enzymology 148: 350382.

Liu, J., Li, J., Su, X. and Xia, Z. 2014. Grafting improves drought tolerance by regulating antioxidant enzyme activities and stress-responsive gene expression in tobacco. - Environmental and Experimental Botany 107: 173-179.

Ma, Q., Turner, D.W., Levy, D. and Cowling, W. 2004. Solute accumulation and osmotic adjustment in leaves of Brassica oilseeds in response to soil water deficit. - Australian Journal of Agricultural Research 55: 939-945.
Manivannan, P.C.A., Jaleel, B., Sankar, A., Kishorekumar, R., Somasundaram, G.M., Lakshmanan A. and Panneerselvam, R. 2007. Growth, biochemical modifications and proline metabolism in Helianthus annuиs L. as induced by drought stress. Colloids and Surfaces B: Biointerfaces 59: 141-149.

Marschner, P. 2012. Marschner's mineral nutrition of higher plants. 3rd ed. Academic Press, London, UK. pp: 178-189.

Masukasu, H., Karin, O. and Kyoto, H. 2003. Enhancement of anthocyanin biosynthesis by sugar in radish (Raphanus sativus) hypocotyls. - Plant Science 164: 259-265.

Munne-Bosch, S. and Alegre, L. 2004. Die and let live: leaf senescence contributes to plant ssurvival under drought stress. - Functional Plant Biology 31: 203-216.

Nagata, M. and Yamashita, I. 1992. Simple method for simultaneous determination of chlorophyll and carotene in tomato fruit. - The Japanese Society for Food Science and Technology-Nippon Shok 39: 925-928.

Neocleous, D. and Vasilakakis, M. 2007. Effects of $\mathrm{NaCl}$ stress on red raspberry (Rubus idaeus L. 'Autumn Bliss'). - Scientia Horticulturae 112: 282-289.

Oliviera-Neto, C.F., Silva-Lobato, A.K., GoncalvesVidigal, M.C., Costa, R.C.L., Santos-Filho B.G., Alves G.A.R., Silva-Maia, W.J.M., Cruz, F.J.R., Neres, H.K.B. and Santos-Lopes, M.J. 2009. Carbon compounds and chlorophyll contents in sorghum submitted to water deficit during three growth stages. Science and Technology 7: 588-593.

Ort, D.R. 2001. When there is too much light. - Plant Physiology 125: 29-32.

Parry, A.D., Tiller, S.A. and Edward, R. 1994. The effects of heavy metals and root immersion on isoflavonoid metabolism in alfalfa (Medicago sativa L.). - Plant Physiology 106: 195-203.

Pastori, G.M. and Trippi, V.S. 1993. Cross resistance between water and oxidative stress in wheat leaves. Journal of Agricultural Science 20: 289 -294.

Pereira, J.S. and Chaves, M.M. 1993. Plant water deficits in mediteranian ecosystems. In: Water Deficits and Plant Growth. Eds. By Kozlowski, T.T. Academic Press, New York. pp: 237.

Plaue, Z., Grava, A., Yehezkel, Ch. and Matan, E. 2004. How do salinity and water stress affect transport of water, assimilates and ions to tomato fruits? Physiologia Plantarum 122: 429-442.

Rebey, I.B., Bourgou, S., Debez, I.B.S., Karoui, I.J., Sellami, I.H., Msaada, K., Limam, F. and Marzouk, B. 2011. Effects of extraction solvents and provenances on phenolic contents and antioxidant activities of 
Cumin (Cuminum cyminum L.) seeds. - Food and Bioprocess Technology 5: 2827-2836.

Rebey, I.B., Jabri-Karoui, I., Hamrouni-Sellami, I., Bourgou, S., Limam, F. and Marzouk B. 2012. Effect of drought on the biochemical composition and antioxidant activities of cumin (Cuminum cyminum L.) seeds. - Industrial Crops and Products 36: 238-245.

Rispail, N., Morris, P. and Webb, K.J. 2005. Phenolic compounds: Extraction and Analysis. In A. J. Marquez, ed. Lotus japonicus Handbook. - Springer, pp: 349355 .

Ruiz, J.M. and Romero, L. 1999. Nitrogen efficiency and metabolism in grafted melon. - Scientia Horticulturae 81: 113-123.

Saeed-Akram, M., Ashraf, M. and Aisha Akram, N. 2009. Effectiveness of potassium sulfate in mitigating saltinduced adverse effects on different physiobiochemical attributes in sunflower (Helianthus annuus L.). - Flora 204: 471-483.

Saftner, R.A. and Wyse, R.E. 1980. Alkali cation/sucrose cotransport in the root sink of sugar beet. - Plant Physiology 66: 884-889.

Serraj, R. and Sinclair, T.R. 2002. Osmolyte accumulation: Can it really help increase crop yield under drought conditions? - Plant Cell and Environment 25: 333-341.

Singh, G.S. and Tuteja, N. 2010. Reactive oxygen species and antioxidant machinery in abiotic stress tolerance in crop plants. - Plant Physiology and Biochemistry 48: 909-930.
Suriyan, Ch. and Chalermpol, K. 2009. Proline accumulation, photosynthetic abilities and growth characters of sugarcane (Saccharum officinarum L.) plantlets in response to iso-osmotic salt and waterdeficit stress. - Agricultural Sciences in China 8: 51-58.

Thalooth, A.T., Tawfik, M.M. and Magda Mohamed, H. 2006. A comparative study on the effect of foliar application of zinc, potassium and magnesium on growth, yield and some chemical constituents of mungbean plant grown under water stress conditions. - World Journal of Agricultural Sciences 2: 37- 46.

Tian, X. and Li, Y. 2006. Nitric oxide treatment alleviates drought stress in wheat seedlings. - Biologia Plantarum 50: 775-778.

Vendruscolo, A.C.G., Schuster, I., Pileggi, M., Scapim, C.A., Molinari, H.B.C., Marur, C.J. and Vieira, L.G.C. 2007. Stress-induced synthesis of proline confers tolerance to water deficit in transgenic wheat. - Journal of Plant Physiology 164: 1367-1376.

Venskutonis, P.R., Miliauskas, G. and Van Beek, T.A. 2004. Screening of radical scavenging activity of so medicinal and aromatic plant extracts. - Food Chemistry 85: 231-237.

Wind, W., Arend, M. and Fromm, J. 2004. Potassiumdependent cambial growth in poplar. - Plant Biology 6: 30-37.

Zhang, K.M., Yu, H.J., Shi, K., Zhou, Y.H., Yu, J.Q. and Xia, X.J. 2010. Photoprotective roles of in Begonia semperflorens. - Plant Science 179: 202-208.

Norastehnia, A. and Farjadi, M. 2016. The effect of the interaction between water stress and potassium nitrate on some of the physiological responses of Nicotiana tabacum L. - Nova Biologica Reperta 2: 260-271.

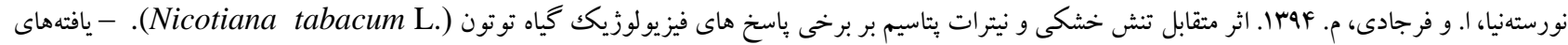

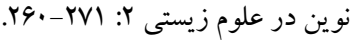

